\title{
Magnesium an Important Nutrient in Pineapple Production in a Bayamón Sandy Clay
}

\author{
E. Hernández-Medina ${ }^{1}$
}

\section{INTRODUCTION}

In a previous paper $(2)^{2}$ studies were reported which demonstrated the outstandingly beneficial effect of magnesium on pineapple growth and production when this nutrient was applied via the soil, or via the foliage of plants grown in a Río Lajas sandy soil, a potentially good soil for pineapple production in Puerto Rico. Evidence was also presented of the ineffectiveness of trace elements on the criteria mentioned above.

This paper reports also on the influence of magnesium and trace elements on pineapples grown in a soil typical of the pineapple-growing region of the Island.

\section{EXPERIMENTAL PROCEDURE}

The investigation began in September 1958, in the northern part of the Island at the Pineapple Farm, Manati, of the Agricultural Experiment Station. The experiment was established on the acid lateritic soil classified as Bayamón sandy clay. It is characterized by having a friable, brownishred, permeable, granular surface soil underlain by a deep-red slightly plastic but permeable clay subsoil (5).

Before planting, the soil was treated with DD at the rate of 30 pounds per acre to control nematodes. Aldrin was used at the rate of 4 pounds of the technical product per acre for controlling white grubs.

Plots $18 \times 63 / 4$ feet, comprising an area of approximately $1 / 359$ of an acre, were used for this study. On each plot 2 rows of pineapples were planted, each row consisting of 12 plants. At this rate a total of 8,816 plants is needed to plant an acre. Slips of the Red Spanish variety were used in this field trial.

The experiment had 16 treatments. There were six replications to each treatment, arranged in a $4 \times 4$ triple-lattice design. The complete fertilizer treatment consisted of all nutrients under test. Other treatments indicated in table 1, except the check, consisted of all nutrients under test, except one element, omitting either magnesium, iron, boron, zinc, copper, or molybdenum. Manganese was not included in this investigation since it has been found previously that the Bayamon soils have sufficient of this nutrient

1 Horticulturist, Agricultural Experiment Station, University of Puerto Rico, Río Piedras, P.R. The author wishes to extend his gratitude to H. Gandía Diaz for his help in connection with the fieldwork.

2 Italic numbers in parentheses refer to Literature Cited, pp. 23-4. 
TABLE 1.-Magnesium and trace elements applied to soil and foliage of pineapple plants grown in Bayamon sandy clay, Manati, P.R. ${ }^{1}$

\begin{tabular}{|c|c|c|c|c|c|c|c|c|c|c|c|c|}
\hline \multirow{2}{*}{ Treatments } & \multicolumn{6}{|c|}{ Soil application } & \multicolumn{6}{|c|}{ Spray applications } \\
\hline & $\mathbf{M g}$ & $\mathrm{Fe}$ & B & $\mathrm{Zn}$ & $\mathrm{Cu}$ & $\mathbf{M o}^{2}$ & $\mathbf{M}_{\mathbf{B}}$ & $\mathrm{Fe}$ & $\mathbf{B}$ & $\mathbf{Z n}$ & $\mathrm{Cu}$ & Mo \\
\hline & $L b . / A$ & $L b . / A$ & $L b . / A$ & $L b . / A$ & $L b . / A$ & $L b . / A$ & $L b . / 100 \mathrm{gal}$. & $\mathrm{Lb} . / 100 \mathrm{gal}$ & $L b . / 100 \mathrm{gal}$. & Lb. $/ 100 \mathrm{gal}$. & $L b . / 100 \mathrm{gal}$. & Lb. $100 \mathrm{gal}$. \\
\hline $\begin{array}{l}\text { Complete, } \mathrm{Mg}+\text { trace ele- } \\
\text { ments-original soil } \mathrm{pH}, 5.0\end{array}$ & 300 & 50 & 40 & 75 & 30 & 2 & 15 & 2 & 2 & 3 & 2 & 1 \\
\hline $\begin{array}{l}\text { Complete, } \mathrm{Mg}+\text { trace ele- } \\
\text { ments-soil limed to } \mathrm{pH} 5.5\end{array}$ & 300 & 50 & 40 & 75 & 30 & 2 & - & 一 & - & - & 一 & - \\
\hline Complete except $\mathrm{Mg}$ & 0 & 50 & 40 & 75 & 30 & 2 & 0 & 2 & 2 & 3 & 2 & 1 \\
\hline Complete except Fe & 300 & 0 & 40 & 75 & 30 & 2 & 15 & 0 & 2 & 3 & 2 & 1 \\
\hline Complete except B & 300 & 50 & 0 & 75 & 30 & 2 & 15 & 2 & 0 & 3 & 2 & 1 \\
\hline Complete except Zn & 300 & 50 & 40 & 0 & 30 & 2 & 15 & 2 & 2 & 0 & 2 & 1 \\
\hline Complete except $\mathrm{Cu}$ & 300 & 50 & 40 & 75 & 0 & 2 & 15 & 2 & 2 & 3 & 0 & 1 \\
\hline Complete except Mo & 300 & 50 & 40 & 75 & 30 & 0 & 15 & 2 & 2 & 3 & 2 & 0 \\
\hline Check, NPK only & 0 & 0 & 0 & 0 & 0 & 0 & 0 & 0 & 0 & 0 & 0 & 0 \\
\hline
\end{tabular}

${ }^{1}$ NPK was supplied in all treatments in a 13-3-12 fertilizer at the rate of 20 cwt. per acre distributed in 3 applications.

2 Refers to sulfates of $\mathrm{Mg}, \mathrm{Zn}$, and $\mathrm{Cu}$. B was added as $\mathrm{Na}_{2} \mathrm{~B}_{4} \mathrm{O}_{7} \cdot 10 \mathrm{H}_{2} \mathrm{O}$, iron as EDTAFe, and $\mathrm{Mo}^{2} \mathrm{Na}_{2} \mathrm{MoO}_{4}$. 
for plant growth (3). Lime was used in one of the complete fertilizer mixtures $(\mathrm{Mg}+\mathrm{T}$. E.) at the rate of 1 ton per acre, to determine whether this material at this rate might have any beneficial effect on plant growth or yield. The quantity of lime used raised the original soil $\mathrm{pH}$ from 5.0 to 5.5. The check treatment consisted of NPK only. Nutrients were supplied via the soil or foliage. Three nutritional sprays were given to the plants according to the treatment schedule. Nufilm was used as a sticker and spreader material.

Nine months after planting, leaf samples were taken from representative plants in the replicated plots of selected treatments for chemical determination of magnesium.

Approximately 1 year after the experiment began the plants were treated with acetylene to induce flowering. Picking of fruits started when the plants were approximately 18 months old, and lasted for a period of about 2 months. The criteria used in the evaluation of the effects of treatment differentials were the weight and amount of marketable fruits, the mean production per acre, and leaf-magnesium content. Magnesium determinations were made on 9-month-old leaves. The active or largest leaf of plants was selected for this purpose (6). The procedure used by Parks et al. (4) was followed for the determination of magnesium, in an effort to discover possible correlations between leaf-nutrient content and yields. A Beckman DU Spectrophotometer was used to determine percentage transmission of the nutrients under study.

\section{EXPERIMENTAL RESULTS}

FIELD DATA

The data obtained with respect to the influence of magnesium and trace elements on yields of the Red Spanish pineapple are shown in table 2. A study of these data reveals that no trace element was responsible for increasing significantly individual weight of fruit or the fruit yield per acre. Magnesium was the only nutrient which had a significant influence in all cases, except for three yields of pineapples, whether it was applied via the roots or foliage of the plants. Plants supplied with magnesium produced on the average 2.7 tons more fruit per acre than plants lacking this nutrient. The determining factors responsible for the lack of a significant response in yields resulting from foliar treatments 11,12 , and 13 , where magnesium was involved, are not clear. As can be seen from table 2, this was not the case for the corresponding soil treatments, 1, 8, and 9, where significant yield differences were obtained. It appears also from table 2 that lime at the rate used did not have any significant effect on yields. Compare treatments 2 and 8.

Figure 1 illustrates graphically the influence of magnesium and trace ele- 
ments on yields, together with the percentage increase in yield, black bar, in favor of magnesium-treated plants over plants not supplied with this nutrient.

\section{LEAF ANALYSES AND REGRESSION STUDIES}

The results of quantitative determinations of leaf magnesium on plants with and without magnesium supplied are presented in table 3 , together with their corresponding yields.

TABLE 2.-Mean yield per acre of pineapples as affected by fertilizer treatments on Bayamón sandy clay

\begin{tabular}{|c|c|c|c|c|}
\hline $\begin{array}{c}\text { Treatment } \\
\text { No. }\end{array}$ & $\begin{array}{l}\text { Method of } \\
\text { fertilizer } \\
\text { application }\end{array}$ & Treatment & $\begin{array}{c}\text { Mean weight } \\
\text { of fruit }\end{array}$ & $\begin{array}{l}\text { Mean yield of } \\
\text { fruit per acre' }\end{array}$ \\
\hline $\begin{array}{r}1 \\
2 \\
3 \\
4 \\
5 \\
6 \\
7 \\
8 \\
9 \\
10 \\
11 \\
12 \\
13 \\
14 \\
15 \\
16\end{array}$ & $\begin{array}{l}\text { Soil } \\
\text { do. } \\
\text { do. } \\
\text { Foliar } \\
\text { do. } \\
\text { do. } \\
\text { Soil } \\
\text { do. } \\
\text { do. } \\
\text { do. } \\
\text { Foliar } \\
\text { do. } \\
\text { do. } \\
\text { Soil } \\
\text { Foliar } \\
\text { Soil }\end{array}$ & 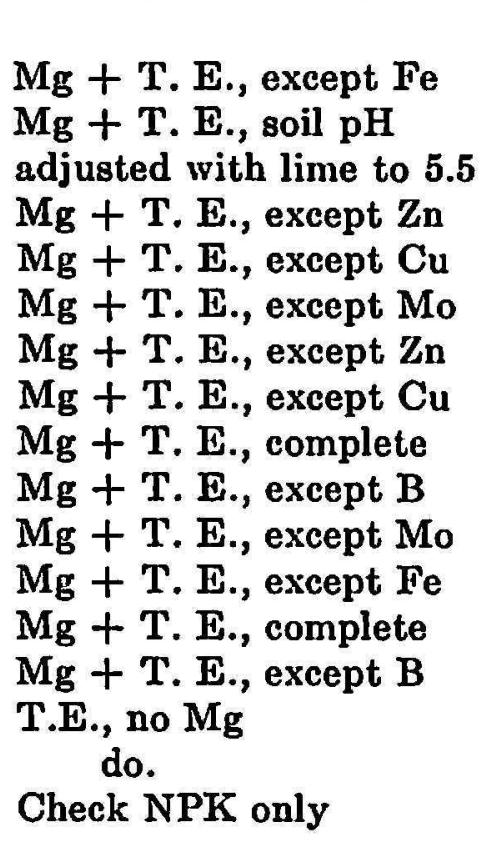 & $\begin{array}{c}\text { Pounds } \\
4.06 \\
\\
4.04 \\
4.03 \\
4.00 \\
3.96 \\
3.95 \\
3.91 \\
3.90 \\
3.86 \\
3.75 \\
3.67 \\
3.65 \\
3.64 \\
3.30 \\
3.26 \\
3.24\end{array}$ & $\begin{array}{c}\text { Tons } \\
17.90^{* *} \\
\\
17.81^{* *} \\
17.76^{* *} \\
17.63^{* *} \\
17.46^{* *} \\
17.41^{* *} \\
17.24^{* *} \\
17.19^{* *} \\
17.01^{* *} \\
16.53^{*} \\
16.18 \\
16.09 \\
16.05 \\
14.55 \\
14.37 \\
14.28\end{array}$ \\
\hline
\end{tabular}

1* Significant at 5-percent level over the last 3 treatments.

** Significant at 1-percent level over the last 3 treatments.

From a study of the data there seems to be a close relationship between leaf magnesium and pineapple yield. Capó and Samuels (1) have shown that the quantitative relationship between plant composition and yield can be well expressed by the following equation:

$$
Y r=A+B \text { arc-tan-percent } N u
$$

where $Y r$ is the relative yield, $A$ and $B$ are constants, and arc-tan-percent $N u$ is the arc, the tangent of which is the percentage of the respective nutrient in the plant on a dry-weight basis. This equation was fitted to 30 individual values the means of which are given by treatments in table 3 . The 


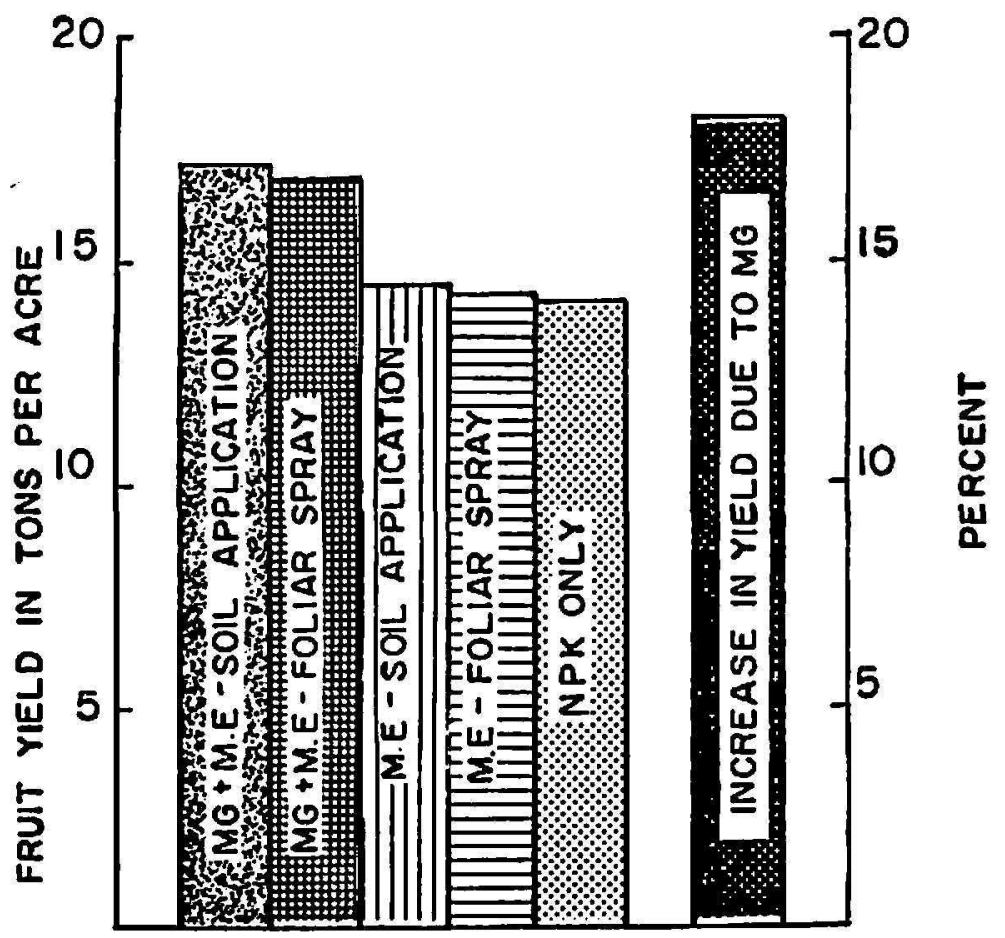

Fig. 1.-Yield of pineapples as related to applications of magnesium and trace elements when grown on a Bayamón sandy clay. Dark bar at right indicates percentage increase in yield in favor of magnesium-treated plants over plants not supplied with this nutrient.

TABLE 3.-Relationship between pineapple fruil yields and lcaf-magnesium content, with and without magnesium supplement

\begin{tabular}{l|l|c|c}
\hline $\begin{array}{c}\text { Type of fertilizer } \\
\text { application }\end{array}$ & \multicolumn{1}{|c|}{ Treatment } & $\begin{array}{c}\text { Mean yields of fruit } \\
\text { per acre }\end{array}$ & Leaf Mg content \\
\cline { 2 - 3 } & & Tons & Percent \\
Soil & $\mathrm{Mg}$ + T. E. & 17.19 & 0.27 \\
Foliar & $\mathrm{Mg}$ + T. E. & 16.09 & .23 \\
Soil & T. E., except $\mathrm{Mg}$ & 14.55 & .13 \\
Foliar & T. E. except Mg & 14.37 & .19 \\
Soil & Check NPK only & 14.28 & .19 \\
\hline
\end{tabular}

formula obtained relating yield and nutrient composition of the pineapple leaf is:

$$
Y r=62.1986+129.2609 \text { (arc-tan-percent } \mathrm{Mg} \text { ) }
$$

The statistical analysis of fitting this equation revealed that the regression of relative yield on arc-tangent-percent magnesium was significant at the 1-percent level, with a coefficient of determination of 30 percent. Figure 2 illustrates graphically the linear relationship between arc-tangent-percent magnesium and pineapple relative yield. 


\section{DISCUSSION AND CONCLUSION}

The information presented in this paper clearly demonstrates once more the outstandingly beneficial effect of magnesium on yields of pineapples when grown on the acid lateritic Bayamón sandy clay, a soil typical of the pineapple-growing region of the Island. It is on this type of soil from which the greatest production of pineapples is obtained.

As was pointed out previously, magnesium was effective in increasing significantly yields of pineapples, whether this nutrient was applied via the roots or to foliage of the plants. It was also evident from the results obtained that both methods of magnesium application were about equally good.

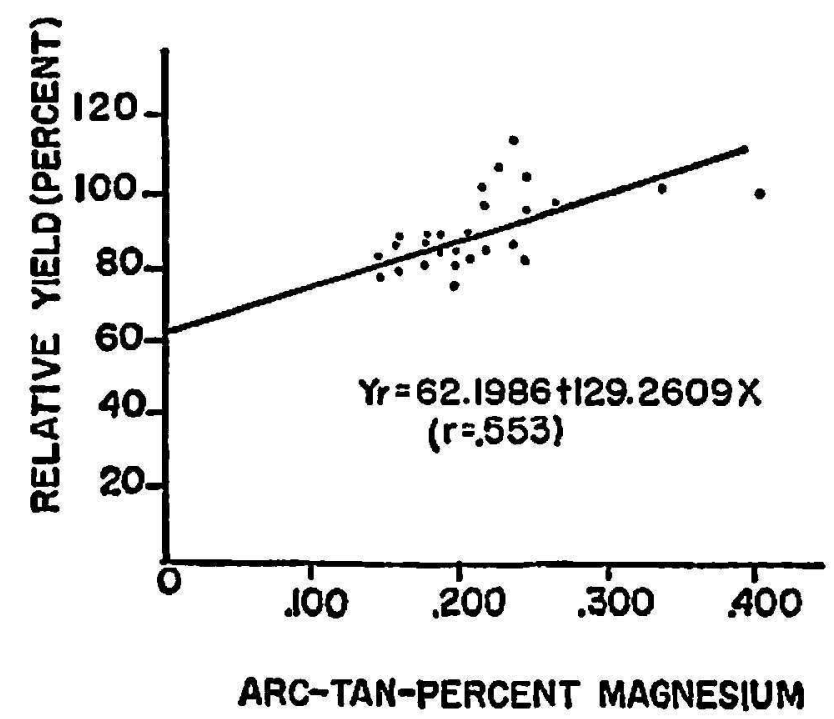

Fra. 2.-Regression of relative yield of pineapple on arc-taugent-percent magnesium.

Although this was the case, it is of interest to point out that much less magnesium was used per acre in a nutritional spray than as a soil application.

From the results presented in this paper it may be concluded that magnesium should be incorporated in the fertilizer mix or applied in foliar sprays, as may be more advantageous in a particular situation so as greatly to increase economical pineapple production.

\section{SUMMARY}

This paper reports the results obtained in studies undertaken to determine the influence of magnesium and trace elements on the yield of pineapples grown in a Bayamón sandy clay, a soil typical of the pineapple-growing area of the Island. The trace elements tested were iron, boron, zinc, copper, and molybdenum. The experimental results gathered are briefly summarized as follows:

1. Neither the use of trace elements nor lime was effective in increasing yields of pineapples significantly. 
2. In most cases magnesium was the only nutrient which significantly influenced pineapple yields. Magnesium-treated plants produced, on the average, 2.7 tons more fruit per acre than the check plants.

3. Highest fruit yields were associated with the highest leaf-magnesium contents.

4. A significant correlation was found between relative yields and leafmagnesium values.

5. Based on the data presented herein it is suggested that magnesium be incorporated in the fertilizer mix or in foliar sprays so as to increase fruit yields per acre, when the magnesium leaf content of plants grown on Bayamón sandy clay falls below 0.20 percent.

\section{RESUMEN}

En este trabajo se informa sobre un estudio llevado a cabo para determinar el efecto del magnesio y elementos menores sobre la producción de la piña cuando esta cosecha se cultiva en el tipo de suelo Bayamón arcilloarenoso. Los resultados obtenidos se resumen a continuación:

1. No hubo aumentos en el rendimiento de la piña que pudieran atribuirse al uso de elementos menores o cal.

2. El magnesio fue el único elemento nutritivo que en la mayoría de los casos favoreció un aumento significativo en la producción. En efecto, las plantas a las cuales se les aplicó magnesio produjeron 2.7 toneladas más de frutas por acre, en promedio, que las que no recibieron dicho elemento nutritivo.

3. Los rendimientos máximos de frutas estuvieron asociados a los valores más altos de magnesio en la hoja.

4. Hubo una correlación significativa entre el rendimiento y el contenido de magnesio en la hoja.

5. De acuerdo con los resultados obtenidos se recomienda incorporar el magnesio en el abono comercial o en aspersiones foliares para aumentar la producción de piñas, cuando el contenido de magnesio en la hoja de plantas sembradas en el tipo de suelo Bayamón arcilloarenoso sea menor de 0.20 por ciento.

\section{LITERATURE CITED}

1. Capó, B. G., and Samuels, G., The development of a mathematical concept to interpret the relation between plant composition and crop yield, J. Agr. Univ. P.R. 37 (4) 249-64, 1953.

2. Hernández-Medina, E., Pineapple response to magnesium in Puerto Rico, Proc. Amer. Soc. Hort. Sci. (Caribbean Region) 6 70-5, 1961.

3. Hopkins, E. F., Pagán, U., and Ramírez-Silva, F. J., Iron and manganese in relation to plant growth and their importance in Puerto Rico, J. Agr. Univ. P.R. 28 (2) 43-101, 1944.

4. Parks, R. Q., Hood, S. L., Hurwitz, Ch., and Ellis, H. G., Quantitative chemical 
microdeterminations of 12 elements in plant tissue, Ind. \& Eng. Chem. Anal. Ed. 15 (8) 527, 1943.

5. Roberts, R. C., Soil Survey of Puerto Rico, USDA, Bureau of Plant Industry in cooperation with the Univ. P.R., Agr. Expt. Sta., Series 1936, (8) p. 503, Jan. 1942.

6. Sideris, C. P., Krauss, B. H., and Young, H. Y. Assimilation of ammonium and nitrate by pineapple plants grown in nutrient solutions and its effect on nitrogenous and carbohydrate constituents, Plant Physiol. 13 489-527, 1938. 